Baltimore: John Hopkins University Press, 1965.

Garskof, B. E., \& Houston. J. P. Measurement of verbal relatedness: An ideographic approach. Psychological Review, 1963. 70, 277-288.

Geesilin. W. E., \& Shavelson, R. J. An exploratory analysis of the representation of a mathematical structure in student's cognitive structure. American Educational Research Journal, in press.

Hotelling. H. The generalization of Student's ratio. Annals of Mathematical Statistics, 1931. 2. 360.378.

Johnson. P. E. Some psychological aspects of subject-matter structure. Journal of Educational Psychologv, 1967, 58, 75-83.

MEAD. M. A. RCMAT-A FORTRAN program to calculate relatedness coefticients among stimulus words by comparing lists of verbal responses to the stimuli. Behavioral Science. 1972. $17,568$.

ShaVelson, R. J. Some aspects of correspondence between content structure and cognitive structure in physics instruction. Journal of Educational Psychology, 1972, 63, 225-234.

Shavelson, R. J. Methods for examining representations of a subject-matter structure in a student's memory. Journal of Research in Science Teaching, 1974, 11, 231-249.

Shavelson. R. J. Some methods of examining content structure and cognitive structure in instruction. Educational Psychologist, in press.

Veldman, D. Fortran programming for the behavioral sciences. New York: Holt, Rinehart and Winston, 1967.

\section{Program to determine growth and decline functions from semi-longitudinal data}

\author{
MARY ANN FISHER \\ Universiț of Mañland Baltimore County \\ Baltimore, Maryland 21228
}

Description. The semi-longitudinal method is appropriate for computing growth functions of subject characteristics when two or more measures are available for each of a large number of subjects over any part of the life span. It is not necessary that the measures be taken at the same chronological ages (CA) for all individuals. The rationale for the semi-longitudinal method is presented in Fisher and Zeaman (1970). The program computes an average slope of the function for each CA interval using data from all subjects whose measures either fall within that interval or span it. These slopes determine the shape of the semi-longitudinal function. The absolute level of the curve is determined by a least-squares fit of the curve to the mean cross-sectional values for each interval. Regression coefficients. $m$ and $b$, are computed for the equation $\dot{x}$ $=\mathrm{m}(1 / \mathrm{CA})+\mathrm{b}$, where $\mathrm{x}$ is the slope of the semi-longitudinal function corresponding to each $\mathrm{CA}$ interval. The correlation coefticient for the regression is also computed. This linear regression function should tit well when the growth function is logarithmic.

Input. A set of input cards containing the information from the Pinneau (1961) tables for an optional MA-to-IQ conversion is unchanging and comes with the program. The user specities the abscissa interval size in months of $C A$ and the increment size for successive least-squares approximations. Average slopes are computed for each of the abscissa intervals. For each subject, the user prepares one punched card record containing a list of successive measures on that subject and the CAs for each measure.

Output. Each input data card is printed followed by the values of the dependent variable after optional conversion and by the first and last $C A$ intervals into which measures for this subject fall. The

The preparation of this manuscript was supported by Grant M-1099 from the National Institute of Mental Health. U.S. Public Health Service. Requests for reprints should be sent to the author: Department of Psychology. University of Maryland Baltimore County. 5401 Wilkens Avenue. Baltimore. Maryland 21228. initial deviations and sums of squared deviations for successive least-squares approximations fixing the level of the curve are printed out. A table is printed containing for each $\mathrm{CA}$ interval: the initial CA in months, the ordinal number of the interval, the weighted mean slope of all line segments in that interval. the number of measures on which the mean is based, mean cross-sectional value of $y$. the dependent variable, the mean semi-longitudinal value of $y$, and the standard deviation of the cross-sectional measures. This table is also punched into cards. A linal table is printed with the regression coefficients. the correlation coefticient, and the observed and estimated values of $x$ at each interval.

User options. The user may specify interval size and least-square increment size. The program may be used with any dependent variable. If the variable is $\mathrm{MA}$, there are optional transformations available in the program to use instead: (1) the $1 Q$ as computed from the in put $\mathrm{MA}$ and $\mathrm{CA}$ by means of the Pinneau tables and functions. or (2) K, the constant of mental growth developed by Fisher and Zeaman. The program will easily accept other transformations of the raw data supplied by the user as subroutines.

Limitations. Current restrictions are arbitrary in that these were established in accordance with expected use rather than in deference to machine limitations. There are up to 100 intervals of CA, up to 11 measures per subject. up to 4.000 measures altogether. Intermediate storage on a scratch tape is required. The total execution time for the IBM 360 to do tive separate analyses. reading a total of 1.500 subject cards averaging four measures each, printing 5.000 lines. and punching 600 cards. was $2.73 \mathrm{~min}$.

Computer and language. The program is written in FORTRAN IV and has been run on both the IBM 7040 and the IBM 360. Since there are no machine-bound parts of the program. it should run on any system having a fully implemented FORTRAN IV capability

Availability. The documented program is available from the author at: Department of Psychology. University of Maryland Baltimore County, 5401 Wilkens Avenue, Baltimore, Maryland 21228 .

\section{REFERENCES}

Fisher, M. A., \& Zeaman, D. Growth and decline of retardate intelligence. In N. R. Ellis (Ed.), International review of research in mental retardation (Vol. 4). New York: Academic Press. 1970. Pp. 151-191.

Pinneau, S. Changes in intelligence quotient: Injancy to maturity. Boston: Houghton Mifflin, 1961. 